\title{
Competitive Strategies and Performance of Construction Companies in Kisumu County, Kenya
}

\author{
Fredrick Abonda ${ }^{1} \&$ Vincent N. Machuki ${ }^{2}$ \\ ${ }^{1}$ Fremerc Builders Limited, Kisumu, Kenya \\ ${ }^{2}$ School of Business, University of Nairobi, Kenya \\ Correspondence: Vincent N. Machuki, School of Business, University of Nairobi, Kenya.
}

Received: October 11, 2018

Accepted: November 9, 2018

Online Published: November 25, 2018

doi:10.5430/jms.v9n4p47

URL: https://doi.org/10.5430/jms.v9n4p47

\begin{abstract}
Competitive strategy is intended to grant an organization the ability to outperform its rivals and gain market leadership. Research on performance implications of competitive strategies is vast strategic management but without much consensus. This study set out to establish the competitive strategies adopted by construction firms in Kisumu County and to determine their influence on the companies' performance. Through a cross sectional descriptive survey, data were obtained from a randomly drawn sample of eighty four (84) construction companies using a structured questionnaire and analyzed using multivariate regression analysis. The findings of the study indicate that the construction firms adopted cost leadership, product differentiation, growth strategies, and grand strategies. The study reports strong positive correlation between competitive strategies and performance as well as statistically significant influence of competitive strategies on performance. Grand strategies account for a larger variation performance followed by generic and growth strategies respectively. Independently, differentiation strategy accounted for a larger proportion of unit change in performance followed by market penetration, strategic alliances and innovation in that order. Out of the study results, the firms are advised to aggressively adopt a mix of competitive strategies. The study's findings support the postulations of game theory and the strategic conflicts model as anchoring theories. Arising from the study's limitations, suggestions for further research have been advanced along different lines.
\end{abstract}

Keywords: competitive strategies, firm performance, construction firms

\section{Introduction}

Over the years several researches have been done by those in the discipline of strategic management to establish the variations in performance of organizations within the same industry. Researchers have established that competitive strategy have some effect on firm performance (Eunice \& Kepha, 2013; Kimani \& Douglas, 2014; Machuki, 2011; Oluoch, 2016). The role of competitive strategy is to set up a financially rewarding and retainable role in opposition to industry forces and rivalry. It entails singling out rivalry assets inside tempestuous surroundings thereafter growing master plan suiting firm skills modified within its surroundings. The organization's rivalry game plan is composed of the plans, measures, tactics and procedures it has and is taking to draw customers, resist competitive stress and enhance how it ranks in the industry (Thompson \& Strickland, 2010). The three generic strategies include; general low-cost manufacturer aspiration, involving cost leadership approach, aspiring to distinguish one's merchandise from that of competitors, and is referred to as differentiation approach, and recognition on a slender market segment, referred to as focus strategy (Porter 2000).

Lester (2009) observed that competitive strategy allows an organization to outline the enterprise presently as well as in the future, and chose the markets to enter into. Ansoff (1991) observes that corporations that have advanced competitive strategies have a tendency to be nicely aligned and bring higher financial effects and performance than those which aren't. This factor to a controversy that the overall performance of a corporation is related to the competitive strategy it adopts.

Kenya's construction sector as anticipated is to witness rapid progress because both the public and private sector are increasing the scope of their projects and are heavily investing in roads, railway, ports, energy and housing development. First, there is a big shortfall in infrastructure-inclusive of roads, rail, energy and ports-provides a 
tremendous exposition for continued growth in the industry, which accounts for $5 \%$ of Kenya's GDP and personnel at least a million people. Second, the souring housing need across the nation is as a result of the rapid increase in population, thus presenting a major opportunity for growth that keeps the private developers rushing to keep up with this demand (Kenya National Bureau of Statistics 2015).

The construction industry in Kisumu County is notably aggressive. There are over two hundred registered construction companies in Kisumu as per the National Construction Authority records (NCA, 2015), and a total of 461 construction companies prequalified with the County Government of Kisumu (CGK) in FY2014-2016 to provide construction services and are actively competing in the industry. This number is expected to increase. Other than warding off competition from the resident construction companies, the free to entry market, globalization and the dynamic nature of technology implies that the construction firms are no longer competing in a localized market but a global market.

Globalization has brought competition closer to home and this has brought with it too much pressure on the management of such firms to develop competitive strategies that will enable the firm to achieve effective and efficient operations that will have a positive implication on their performance. Building and construction industry has customarily worked in a pretty reasonable condition for a long time. But, these days the business is confronting drastically competitive opposition in another regulations free condition (Reynolds, 2005).

Competitive strategies adopted by companies in their operations fluctuate broadly in light of the working condition. Kisumu County's construction industry is presumed to be very dynamic and profoundly competitive with the emergence of many new registered resident contractors as well as non-resident contractors. Construction firms in Kisumu County are establishing that fierce rivalry in the sector requires the outline of competitive techniques to guarantee their performance. The capability of a company to command a competitive gain is based at the sustainability of the competitive advantages that they can direct with a specific authority. The business operating condition in the nation has fundamentally transformed resulting in some construction firms opening some branches across borders of county and country and thus growing competition in the industry globally. It is critical that every construction organization has to take into account a way to enter a market and then build and guard its competitive position.

A number of empirical studies (Dess \& Davis, 1984; Hawes and Crittendon, 1984) found that business strategy had significant effect on organizational performance of SMEs in Ghana. Despite the fact that, other research (Chan \& Wong, 1999; Hlavacka, Ljuba, Viera \& Robert, 2001) verified that cost leadership and differentiation techniques are not totally unrelated; they can be merged to get preferred general performance over a solitary technique. Other studies have been done in this line in Kenya, for example Wambugu (2012), studied competitive strategies and performance of NGOs in Nairobi; Oyeila (2011) and Karanja (2010) studied the effect of competitive strategies on commercial banks' performance and noted that strategies adopted contributed to increased networking and customer base; Adhiambo (2009) established that organizations must repackage their products and services, be imaginative and move with innovation for survival in the so powerful and turbulent business environment in her research to determine the influence of competitive position on commercial bank's performance; Obiero (2008) put emphasis on competitive strategies adopted by Kenya's cement manufacturing companies and observed that pricing of products, low cost of materials and proximity to customers were among the key strategies.

The above mentioned studies were done on competitive strategies and their relationship to performance. However, these studies were focused on specific firms which operate in different industries. In general, the studies were meant to determine the connection between various strategies and performance of the companies that adopted them. However, a study to determine the connection between competitive strategies and their influence on the performance targeting construction companies in Kisumu County has probably not been done. Therefore, this study sought to address this gap in knowledge. What is the influence of competitive strategies on performance of construction companies in Kisumu County? To answer this research question, the study sought to establish the competitive strategies adopted by the firms and to determine the influence of the strategies on the performance of the firms.

\section{Literature Review}

The competitive strategy of companies is anchored in theoretical propositions of game theory (Osborne \& Rubinstein, 1994) and strategic conflict model (Shapiro, 1989). Game Theory and Strategic Conflicts Model explain the way organizations are affected by the environment and how they can use the resources that they have to gain competitive advantage. Firms make strategic choices that a manager will observe in each feasible workable state of affairs in an industry to reap a bonus over his firms competitors. In times of uncertainty, Weidinger \& Platts (2012) advises that a 
set of standards aimed at decision making in situations of competition and conflict referred to as game theory to be used.

The standards of game theory offer a language to formulate structure, examine, and recognize strategic eventualities which play important position in strategic management of corporations. Strategic conduct display that one characteristic of a successful method is unpredictability which indicates the opportunity of a deliberately randomized strategy (Wigner, 2010). A strategic game represents a state of affairs where two or more participants are faced with selections of action, by which each can gain or lose, depending on what others pick out to do or not to do. The final result of a game, therefore, is decided jointly by the techniques chosen by all contributors. Canary \& Lakey (2012) said that the results of tactical leadership and decision making, which might all be fundamental for more appropriate organizational performance, do never again calmly exist together. Incongruity is by all accounts the core of this problem and all things considered, a superior comprehension of dispute's impacts on key basic leadership and decision making is required. Substantive friction is normal inside best administration groups as executives' battle with settling on high-stakes decisions under states of equivocalness and vulnerability.

The stature of game theory has soared in the last five decades, and has been of great importance in a number of disciplines of the social sciences (Lim, 1999). The concern first outlined zero-sum games, such that one character's gains are precisely same net losses of the alternative player. Turocy \& von Stengel (2001) described game theory as a conventional research of selection-making where a number of participants ought to make alternatives that doubtlessly have an effect on the pursuits of other players.

Game theory applies in lots of studies of competitive scenarios, consequently the problems are known as games and the members are called players. A participant is described by Osborne (2002) as a person or group of individuals making a decision. Camerer et al., (2001) went on to define the assumptions of the game theory as that, all players form beliefs based totally on evaluation of what others would possibly do, pick a pleasant reaction given the ones beliefs, and regulate excellent responses and ideals till they are identical. Camerer et al., (2001) emphasized that those assumptions are once in a while violated, that means that now not every player behaves rationally in tough situations. Osborne \& Rubinstein (1994) additionally highlighted that the fundamental assumption that motivates the game theory is that decision-makers are rational and that they act strategically. Osborne \& Rubinstein (1994) similarly stated that decision-makers are privy to their options and chooses their action intentionally after some process of optimization.

Strategic conflict evaluation involves analyzing a particular conflict to its causes and viable outcomes offering expert recommendation to policymakers. It's supposed to understand conflict and prevent its outbreaks in the future (Johnson, 1999). Strategic conflict model is one of the rivalry based hypotheses of business methodology. The strategic conflict model augments Porter's generic strategies in that it perceives the capacity an organization needs to control its commercial center condition, as a result enhancing its competitive standpoint. Utilizing a game theoretic foundation, strategic conflict can assist companies perceive and pursue a desired position within their industry. As firms take action, additionally they count on what movement they believe their competitors will take. Shapiro highlighted a number of the potential strategic "movements" such as product standardization (in highly networked industries), strategic control of data (impacting rival organizations' beliefs about market conditions), investment in physical capital, investment in intangible assets (for example R\&D), horizontal mergers, and strategic contracting (Shapiro, 1989).

Teece et al., (1997) factor out that the pertinence of making utilization of strategic conflict's gaming standards can be set one of a kind. For instance, an organization that overwhelmingly rules a given industry should not have to be as mindful of opponent company's diversions as an organization in an industry where the competitive benefits are additional inconspicuous or uniformly scattered, likewise strengthening the statute that they need for a technique is pushed through the duration of rivalry.

\subsection{Competitive Strategies}

The term strategy is described as scheme, policy, grand design employed in maneuvers, moves, role and stratagem intended to outsmart competition at the same time as fulfilling stakeholders' expectations consistent with the enterprise's scope of commercial enterprise (Mintzberg, 1994). Competitive strategy is subsequently an endeavor to attempt and modify an organization's competency with respect to the rival's in adequate productive manner and furthermore to form activities and choices of administrators and work force in an organized, firm-wide recreation designs (Johnson, 2008). 
Companies require competitive strategies for their survival. This is specially the case if the firm is contending in markets overflowing with alternatives for purchasers. In line with Thompson et al., (2004), a competitive strategy refers to an extended-time period plan of action that an organization devises toward accomplishing a competitive advantage over its competitors after establishing the strengths and weaknesses of the latter and comparing them to its own. There are essential styles of competitive advantage an organization can employ to harvest: low-cost or differentiation. The two major sorts of competitive strategy blended with the extent of exercises for which a firm tries to accomplish them, prompt three well known generic strategies for achieving improved performance in a sector, and include: cost leadership, differentiation, and focus. The focus strategy has two variants, cost focus, and differentiation focus (Porter, 2005).

One of Porter's generic strategies is the cost leadership strategy and is utilized as a part of business methodology (Porter, 2005). Cost leadership strategy depicts an approach to set up the upper hand of a firm over adversaries. In fundamental words, it infers the most decreased business operation cost. It is very often directed by company productiveness, capacity, magnitude, purview and average knowledge, and skill. The low-cost strategy desires to utilize size of production, very much determined range and different economies, for example, a great buying technique, delivering exceptionally institutionalized items, utilizing high innovation among others. A number of organizations pick a vital blend to accomplish market leadership. Cost leadership, predominant customer care, and product leadership constitute the strategic mix.

There are ten cost accelerators that Porter (2005) recognized to decide the cost conduct of different esteem exercises. Consequently, a firm that is seeking after a cost leadership strategy ought to have a high score on the greater part of the ten price drivers. The ten cost drivers recognized by Porter are economies of scale which will show itself through product improvement, big scale advertisement, and scale delicate firm framework, the geographical organization of sales force rather than product line organization, research and development of up to date items or copies and decrease in freight costs. Learning which the second driver is shows itself through work productivity change, item plan adjustment, enhanced planning, yield change and enhanced usage of resources. Additional cost drivers include the design of capacity use, internal and external linkages, sharing of assets and procedures in the organization and its esteem chain, combination of significant worth exercises, activity timing, optional strategies, the area of significant worth exercises and institutional components.

A cost pioneer will acquire better than expected return as argued by Porter, and subsequently it is additionally expected that the organizational performance of the company may ameliorate. As indicated by Allen et al. (2006), a company outlining, creating and advertising its services or products more productively than its rivals is considered to have executed a cost leadership strategy. The strategies to reduce cost procedures over the action cost chain will speak to enhance low cost control. Endeavors to lessen expenses will proliferate through the entire business process from item configuration to the last phase of offering the item. Akan et al., (2006) advises that an organization should work to being a low cost leader by outsource activities that don't contribute towards minimization of cost base to other companies.

Low expenses will allow a firm to offer generally institutionalized items that offer highlights worthy to numerous clients at the most minimal focused cost and such low costs will increase competitive advantage and increment piece of the overall industry share. And thus clarifies that the cost effectiveness picked up in the entire procedure will empower a company to mark up a cost lower than the rival which at last leads in high deals since rival couldn't match such a minimal pricing base. Jassim (2008) clarified that the essential concentration of a low-cost technique is to accomplish low costs in respect to contenders. As per Porter (2005), the key rationale of cost authority demands an organization to occupy the cost pioneer position, not any of the few companies competing for this position.

Differentiation strategy is one of Porter's (2004) generic strategies and includes making an item that is seen as special. According to Jassim (2000), differentiation's essential concentration is making uniqueness with the end goal that the firm's merchandise and services are unmistakably recognized from those of its rivals. Porter (2005) contended that a company makes an incentive for a consumer by either bringing down purchaser cost or raising purchaser execution, by bringing down conveyance, establishment or financing costs, bringing down the required rate of utilization, bringing down direct cost of upkeep or space, incidental costs, danger of item malfunction and bringing down the consumer cost in other esteem exercises. Increasing the purchaser performance incorporates surpassing the purchaser's coveted performance, meeting purchaser's non-monetary objectives and fulfilling their requirements in a superior manner (Porter, 2005). On the off chance that a firm effectively wins a premium cost in surfeit of differentiation cost then its profits will be better than expected to bring about enhanced firm performance. 
Another strategy is the focus strategy which affords an enterprise opportunity to concentrates its exertion on one specific section of the market; gives attention to low cost or differentiation in its objective portion in a constrained competitive latitude and means to end up plainly understood for giving products or services for that division. Focus strategy enables a firm to form a competitive advantage by providing goods or services that satisfy the needs of their specialty customers. A firm has the option to seek after cost leadership strategy or differentiation strategy to suit it to the market segment it has chosen. The focus strategy is known as a restricted strategy on the grounds that the business is concentrating on a limited (particular) portion of the market. Porter (2005) pointed out that the focus strategy has two variations; cost center and differentiation center. Cost center endeavors contrast in cost conduct while on the other hand differentiation center adventures extraordinary requirements of the purchasers in a specific segment. While embracing a narrow focus, the firm in an ideal environment focuses on several objective markets.

A firm in an ideal environment will focuses on several objective markets (additionally referred to as division technique or specialty strategy) if it opts to embrace a narrow focus strategy (Reck et al, 2008). The target market ought to be a well-defined class with particular needs. A choice of offering low costs or differentiated products should depend upon the prerequisites of the chosen portion and the assets and abilities of the company. Strategy specialists have indicated that an organization can better address the needs of a target market if it concentrates its marketing endeavors on maybe a couple narrow market segments and fitting its marketing mix to these particular markets. An organization commonly hopes to pick up a competitive advantage through commodity or service advancement and additionally label promoting as opposed to efficiency. The strategy is most reasonable for generally modest enterprise yet can be utilized by any organization. This strategy is suitable for organizations targeting trade sections that are less susceptible to substitutes or where the rivalry is weakest to gain better than expected rate of return. Subsequently, firm performance is required to ameliorate. Reck et al, (2008) assert that in embracing a wide focus scope, the guideline is the same: the organization should learn the requirements and needs of the mass market, and contend either on value (minimal price) or differentiation (Standard, quality, and label) contingent upon its assets and abilities.

Ansoff (1991) provided a grid that focused on the organization's available and potential stock and markets (clients) to indicate possible growth strategy. Through the means of thinking about methods of progressing through current products and advanced products, and in present trades and advanced trades, there exist four viable product-market mixtures. Ansoff's network provides four one-of-a-kind corporate growth techniques: market penetration - the firm tries to expand with existing merchandise in their present market sections, intending to expand its percentage of the market proportion, market advancement - company looking for increment with the guide of focusing on its present merchandise to new market divisions, merchandise improvement - the organization grows new stock focused to its present market portions and broadening - the company develops methods for enhancing into new ventures by growing new items for product spanking into fresh territories (Ansoff, 1991).

The grand strategy frequently is considered the principal strategy to bring forth simple direction for strategic actions. They may be the premise of composed and supported endeavors coordinated in the direction of accomplishing long term enterprise goals. Pearce et al. (2010) have deliberated about fifteen principal grand strategies that strategists ought to recollect. The 15 principal grand strategies are; joint ventures, vertical integration, concentrated growth, conglomerate diversification, market development, product development, innovation, horizontal integration, concentric diversification, turnaround, divesture, liquidation, bankruptcy, strategic alliances, and consortia (Pearce et al., 2010). Either of Pearce and Robinson's grand strategies might need to fill in as the thought for accomplishing the prevalent long time objective of a solitary organization. Many corporations that are worried with more than one industries, agencies, and product lines, or consumer groups typically integrate several grand strategies.

\subsection{Organizational Performance}

Performance can be described as component of monetary as well as nonfinancial indicators which provide information on degree of achievement of goals and impacts (Kaplan and Norton, 1993). Organization's central purpose in any business venture is consistent performance since it can only be able to develop and advance through better performance. Therefore, one of the most imperative factors within management studies is organizational performance and is apparently the most pivotal indicator of the competitive technique adopted.

The significance of strategic performance computation has risen significantly in the most recent couple of years. Recreation and performance aligned administration crusaders pushed for improved performance quantification to get more prominent responsibility as well as enhanced firm productivity (Ingraham, 2005). Numerous firms esteem performance measurement and use it as a method for establishing how well they are performing (Van Dooren, 2010). 
Defenders of performance measurement advocate for using a wide range of sorts of measures to illustrate different aspects of performance and give an unbiased and far reaching perspective of an organization's performance.

Organizational performance alludes to the capacity of an organization to achieve such objectives as; production of superior products, commanding huge market share, generation of high profit, legitimate financial outcomes, and survival during turbulent times while employing appropriate strategies for activity (Koontz \& Donnell, 2003). Organizational performance additionally can be utilized to see how a company is getting along compared to other organizations it shares the industry with on matters; quality of the product, its percentage share of the market and profit levels. It is an impression of the fecundity of company resources measured in terms of profit, development, sales, and growth of the firm (Johnson et al., 2006).

Organizational performance can be measured holistically using Kaplan and Norton's (2006) sustainability balanced scorecard. The sustainability balanced scorecard offer directors a quick however entire perspective of the business. The Balanced Scorecard is an evaluation framework as well as moreover an administration framework, which enables organizations to elucidate their vision and approach and make an interpretation of them without hesitation (Kaplan \& Norton, 2006). The sustainability balanced scorecard provides input round both the inner business procedures and outer results with a view to continually improve vital execution and results. While completely conveyed, the sustainability balanced scorecard changes strategic plan from an instructive exercise into the operational hub of a corporation. The balanced scorecard incorporates both monetary actions that illuminate the after effects of moves officially taken, and operational actions driving subsequent general monetary accomplishments (Kaplan \& Norton, 2006).

\subsection{Competitive Strategies and Firm Performance}

Previous studies have demonstrated that there might be a strong connection between competitive strategies and the performance of companies. Many study findings that deduced roughly the exceptional correlation between competitive strategies and the performance of organizations (Eunice \& Kepha, 2013; Oluoch, 2016; Kimani \& Douglas, 2014; Machuki, 2011; Wambugu, 2012).

Several studies have empirically researched the impact of Porter's competitive strategies on the general performance of enterprises. Kalia (2012) studied the competitive strategies adopted by Chinese firms in the construction industry in Kenya and established that they embraced generic strategies, growth strategies and grand strategies to sustain their performance. Eunice and Kepha (2013) researched on the influence competitive strategies had on the performance of Kijabe hospital. They found that performance was greatly influenced by cost leadership strategy followed by product development, market development, focus strategy and least influential strategy was differentiation. Dess and Davis (1984) studied the general performance results of the competitive strategies in the manufacturing SMEs in Ghana. In their study, they found that those organizations can be sorted into four groups construct absolutely in light of the competitive techniques that they embrace: cost leadership, stuck in the center, focus and differentiation. In expressions of financial progress, the four organizations were seen to be remarkably particular from each other. It was noticed that focus category firms experienced the best earnings burgeon, followed by cost leadership, differentiation and stuck in the middle groups. As far as profit for general resources, the performance contrast was not critical among the four firms. While the most elevated return was clear in the cost leadership gathering, the least was apparent in the focus gathering.

Powers and Hahn (2004) studied the effect of competitive strategies on firm performance in the banking industry. The findings of their study showed that banks fall into five categories fundamentally in view of the type of approach they utilized: standard differentiation technique, focus strategy, stuck in the middle, low-cost strategy and client bolster differentiation system. Their findings set up that, ordinary organizations utilizing competitive strategy perform better (in expressions of profit for property) compared to those stuck in the middle. Organizations that adopted cost leadership strategy registered impressively higher performance compared to those stuck in the middle. In any case, other technique firms couldn't increase extensive general performance advantage over the stuck in the middle category.

\section{Conceptual Framework}

The conceptual framework depicted in the conceptual model (Figure 1) was applied to guide the study. The independent variables for the study weree three broad competitive strategies namely: generic strategies, growth strategies and grand strategies. Each of them was examined to find out their effects on the organizational performance of the construction companies operating in Kisumu County. The sustainable balanced scorecard perspectives were used to operationalize and measure organizational performance as the dependent variable in the study. 
Competitive Strategies

Performance

\begin{tabular}{|l|}
\hline Generic Strategies \\
- Cost Leadership Strategy \\
- Differentiation Strategy \\
- Focus Strategy \\
Growth Strategy \\
- Market Penetration \\
- Market Development \\
- Product Development \\
- Diversification \\
Grand Strategies \\
- Joint Venture \\
- Innovations \\
- Business Integration \\
- Strategic Alliance \\
- Innovation
\end{tabular}

Independent Variables

$\longrightarrow$\begin{tabular}{ll} 
Performance \\
$\bullet$ & Financial Performance (Profitability, Sales \\
& Growth) \\
$\bullet$ & Customer Satisfaction \\
$\bullet$ & Learning \& Growth \\
$\bullet$ & Internal Business Processes \\
$\bullet$ & Environmental Safety and Corporate Social \\
& Responsibility \\
\hline
\end{tabular}

Dependent Variable

Figure 1. Conceptual Mode

\section{Methodology}

\subsection{Study Design}

The study used a cross sectional descriptive survey. A cross-sectional study is the simplest variety of descriptive or observational epidemiology that can be conducted on representative samples of a population. The choice is necessitated by the nature of data to be collected, which is cross sectional. Cooper and Emory (1985) contend that the surveys are more efficient and economical than observations. It also allows for comparative analysis in order to obtain rational conclusions.

\subsection{Population and Sample Design}

The study population was 200 NCA listed resident construction firms in Kisumu County. To compute the sample size, the researchers utilized a simple formula provided by Yamane (1967). Calculations of sample size using this formula was done with assumptions of $95 \%$ confidence level and $\mathrm{P}=0.5$.

$$
n=\frac{N}{1+\mathrm{N}\left(\mathrm{e}^{2}\right)}
$$

Where;

$\mathrm{n}$ is the sample size

$\mathrm{N}$ is the population size $=200 \mathrm{NCA}$ registered construction firms in Kisumu County,

$\mathrm{e}$ is the level of precision $=5 \%$.

The formula was applied to arrive at the sample size as follows;

$$
\mathrm{n}=\frac{200}{1+200\left(0.05^{2}\right)}=134
$$




\subsection{Research Instrument and Data Collection}

A structured questionnaire with closed-ended questions was used to collect data for the study. The questionnaire was developed based on the literature and similar past empirical studies with modifications to suit the context of the current study. The questionnaire was administered through mail to the respondents who were top managers in the sampled construction firms.

\subsection{Data Analysis}

In this study, the objective was to examine the influence of competitive strategies on firm performance. This necessitated the use of multiple correlation analysis to analyze the multivariate relationships. A regression model to guide the analysis was developed and was conducted at $95 \%$ level of confidence $(\mathrm{p} \leq 0.05)$.

Performance $=\mathrm{f}($ Generic Strategies + Growth Strategies + Grand Strategies + Error $)$

Where;

$$
y=\beta o+\beta_{1} x_{1}+\beta_{2} x_{2}+\beta_{3} x_{3}+\varepsilon
$$

$y$ is the performance; $\beta_{\mathrm{o}}$ is the constant; $\beta_{1}$ is the coefficient of generic strategies; $x_{1}$ is generic strategies; $\beta_{2}$ is the coefficient of growth strategies; $x_{2}$ is growth strategies; $\beta_{3}$ is the coefficient of grand strategies; $x_{3}$ is grand strategies; $\varepsilon$ is precision error at $95 \%$ confidence level.

\section{Study Response Rate}

The researchers distributed 134 structured questionnaires to the top and/or section managers of each of the sampled firms out of which 84 were filled and returned. This was a $62.7 \%$ response rate. This response rate was considered acceptable for this study to warrant statistical analysis. According to Mugenda and Mugenda (2003), in a survey design, the expected response rate is $50 \%$. Machuki (2011) posited that a $43.3 \%$ response rate was justified for a study conducted through administering of questionnaires.

\section{Findings}

The findings of the study are presented and discussed in the subsequent sections.

\subsection{Generic Strategies and Performance}

The study carried out the test of the influence of the generic strategies of cost leadership, differentiation and focus on performance. The findings are presented in Table 1.

Table 1. Generic strategies and performance

\section{Model Summary}

\begin{tabular}{|c|c|c|c|c|c|c|c|c|}
\hline \multirow[t]{2}{*}{ Model } & \multirow[t]{2}{*}{$\mathrm{R}$} & \multirow{2}{*}{$\begin{array}{l}\mathrm{R} \\
\text { Square }\end{array}$} & \multirow{2}{*}{$\begin{array}{l}\text { Adjusted } \\
\text { R Square }\end{array}$} & \multirow{2}{*}{$\begin{array}{l}\text { Std. Error } \\
\text { the Estimate }\end{array}$} & \multicolumn{4}{|c|}{ fChange Statistics } \\
\hline & & & & & \multicolumn{2}{|c|}{ R Square ChangeF Change } & df2 & Sig. F Change \\
\hline 1 & $.938^{\mathrm{a}}$ & .880 & .877 & .21828 & .880 & 284.301 & 116 & .000 \\
\hline \multicolumn{9}{|c|}{$\begin{array}{l}\text { a. Predictors: (Constant), Cost leadership, Differentiation, Focus } \\
\text { ANOVA }^{\mathbf{a}}\end{array}$} \\
\hline \multirow[t]{2}{*}{$\overline{\text { Model }}$} & & & \multicolumn{2}{|c|}{ Sum of Squares } & $\overline{\mathrm{Df}}$ & Mean Square & $\mathrm{F}$ & Sig. \\
\hline & \multicolumn{2}{|c|}{ Regression } & \multicolumn{2}{|l|}{40.637} & 3 & 13.546 & 284.301 & $.000^{\mathrm{b}}$ \\
\hline \multirow[t]{2}{*}{1} & \multicolumn{2}{|c|}{ Residual } & 5.527 & & 116 & .048 & & \\
\hline & \multicolumn{2}{|c|}{ Total } & \multicolumn{2}{|l|}{46.164} & 119 & & & \\
\hline \multicolumn{9}{|c|}{ a. Dependent Variable: Overall Performance } \\
\hline
\end{tabular}

\section{Coefficients $^{\mathrm{a}}$}

Model

Unstandardized Coefficients

$\begin{aligned} & \text { Standardized } \\ & \text { Coefficients }\end{aligned}$
Sig.




\begin{tabular}{lllllll}
\hline & B & Std. Error & Beta & & \\
\hline \multirow{3}{*}{1} & (Constant) & .073 & .215 & & .338 & .736 \\
\cline { 2 - 7 } & Cost Leadership & .162 & .035 & .192 & 4.686 & .000 \\
\cline { 2 - 7 } & Differentiation & .600 & .029 & .823 & 20.384 & .000 \\
\cline { 2 - 6 } & Focus & .187 & .049 & .125 & 3.786 & .000 \\
\hline
\end{tabular}

a. Dependent Variable: Overall Performance

The results show a strong positive correlation between generic strategies and performance $(\mathrm{r}=0.938)$ and statistically significant influence of the strategies on performance $\left(r^{2}=0.880 ; p<0.05\right)$. All the strategies have independent influence which is statistically significant $(\mathrm{p}<0.05)$ with differentiation accounting for a higher unit change in performance $(\beta=0.823)$. This can be represented as:

$$
\mathrm{Y}=0.073+0.192 x_{1}+0.823 x_{2}+0.125 x_{3}+\varepsilon
$$

Where $\mathrm{Y}$ is the performance; $x_{1}$ is the cost leadership strategy, $x_{2}$ is the differentiation strategy, $x_{3}$ is the focus strategy and $\varepsilon$ is the precision error term.

\subsection{Growth Strategies and Performance}

The study carried out the test of the influence of the growth strategies of market penetration, market development, product development and diversification on performance. The findings are presented in Table 2.

Table 2. Growth strategies and performance

\begin{tabular}{|c|c|c|c|c|c|c|c|c|c|}
\hline \multicolumn{10}{|c|}{ Model Summary } \\
\hline \multirow[t]{2}{*}{ Model } & \multirow[t]{2}{*}{$\mathrm{R}$} & \multirow[t]{2}{*}{ R Square } & \multirow{2}{*}{$\begin{array}{l}\text { Adjusted } \\
\text { Square }\end{array}$} & \multicolumn{2}{|c|}{ RStd. Error ofChange Statistics } & \multirow[b]{2}{*}{ F Change } & \multirow[b]{2}{*}{ df1 } & \multirow[b]{2}{*}{ df2 } & \multirow[b]{2}{*}{$\begin{array}{l}\text { Sig. } \\
\text { Change } \\
\end{array}$} \\
\hline & & & & the Estimate & R Square Change & & & & \\
\hline 1 & $.773^{\mathrm{a}}$ & .597 & .583 & .40218 & .597 & 42.601 & 4 & 115 & .000 \\
\hline \multicolumn{10}{|c|}{ a. Predictors: (Constant), Diversification, Market Development, Market Penetration, Product Development } \\
\hline \multicolumn{10}{|c|}{ ANOVA $^{\mathrm{a}}$} \\
\hline \multirow[t]{2}{*}{ Model } & & & \multicolumn{2}{|c|}{ Sum of Squares } & \multicolumn{2}{|c|}{ Mean Square } & $\mathrm{F}$ & & Sig. \\
\hline & Regress & & 27.563 & & 6.891 & & 42.601 & & $.000^{\mathrm{b}}$ \\
\hline \multirow[t]{2}{*}{1} & Residua & & 18.601 & & .162 & & & & \\
\hline & Total & & 46.164 & & 119 & & & & \\
\hline \multicolumn{10}{|c|}{ a. Dependent Variable: Overall Performance } \\
\hline \multicolumn{10}{|c|}{ b. Predictors: (Constant), Diversification, Market Development, Market Penetration, Product Development } \\
\hline \multicolumn{10}{|c|}{ Coefficients $^{\mathrm{a}}$} \\
\hline \multirow[t]{2}{*}{ Model } & & & & \multicolumn{3}{|c|}{$\begin{array}{r}\text { Unstandardized Coefficients Standardized } \\
\text { Coefficients }\end{array}$} & \multicolumn{2}{|l|}{$\mathrm{t}$} & \multirow[t]{2}{*}{ Sig. } \\
\hline & & & & $\mathrm{B}$ & Std. Error & eta & & & \\
\hline \multirow{5}{*}{1} & (Cons) & $\operatorname{tant)}$ & & 1.792 & .162 & & 11.042 & & .000 \\
\hline & Marke & t Penetratio & & .260 & .039 & 96 & 6.581 & & .000 \\
\hline & Marke & t Developm & & .194 & .046 & 95 & 4.251 & & .000 \\
\hline & Produ & ct Developn & & -.041 & .035 & 107 & -1.149 & & .253 \\
\hline & Divers & ification & & .058 & .033 & 33 & 1.748 & & .083 \\
\hline
\end{tabular}

a. Dependent Variable: Overall Performance

The results show a fairly strong positive correlation between generic strategies and performance $(\mathrm{r}=0.773)$ and statistically significant influence of the strategies on performance $\left(r^{2}=0.597 ; p<0.05\right)$. Market penetration and market development strategies have statistically significant independent influence $(\mathrm{p}<0.05)$ while product development and diversification strategies have statistically not significant independent influence $(p>0.05)$ with negative effect from 
product development. Market penetration accounting for a higher unit change in performance $(\beta=0.596)$. This can be represented as:

$$
\mathrm{Y}=1.792+0.596 x_{1}+0.295 x_{2}-0.107 x_{3}+0.133 x_{4}+\varepsilon
$$

Where $\mathrm{Y}$ is the performance; $x_{1}$ is the market penetration, $x_{2}$ is the market development, $x_{3}$ is the product development $x_{4}$ is the diversification and $\varepsilon$ is the precision error term.

6.3 Grand Strategies and Performance

The influence of the grand strategies (joint venture, innovation, strategic alliance, and business integration) was tested on performance. The findings are presented in Table 3.

Table 2. Grand strategies and performance

\begin{tabular}{|c|c|c|c|c|c|c|c|c|c|}
\hline \multicolumn{10}{|c|}{ Model Summary } \\
\hline \multirow[t]{2}{*}{ Model } & R Square & \multirow{2}{*}{\multicolumn{2}{|c|}{$\begin{array}{l}\text { Adjusted Std. Error c } \\
\text { R Square the Estimate }\end{array}$}} & fChange Statistics & & & & \multirow{2}{*}{\multicolumn{2}{|c|}{ Sig. F Change }} \\
\hline & & & & R Square Change & F Change & df1 & df2 & & \\
\hline 1 & $.992^{\mathrm{a}} .984$ & .984 & .07980 & .984 & 1783.758 & 4 & 115 & \multicolumn{2}{|c|}{.000} \\
\hline \multicolumn{10}{|c|}{ a. Predictors: (Constant), Business Integration, Innovation, Joint Venture, Strategic Alliance } \\
\hline \multicolumn{10}{|c|}{ ANOVA $^{a}$} \\
\hline \multicolumn{2}{|l|}{ Model } & \multicolumn{2}{|c|}{ Sum of Squares } & df & \multicolumn{2}{|c|}{ Mean Square } & \multicolumn{2}{|c|}{$\mathrm{F}$} & Sig. \\
\hline \multicolumn{2}{|c|}{ Regression } & \multicolumn{2}{|l|}{45.432} & 4 & \multicolumn{2}{|l|}{11.358} & \multicolumn{2}{|c|}{1783.758} & $.000^{\mathrm{b}}$ \\
\hline \multirow{2}{*}{$\frac{\mathrm{R}}{\mathrm{T}}$} & Residual & \multicolumn{2}{|l|}{.732} & 115 & \multicolumn{2}{|l|}{.006} & & & \\
\hline & & \multicolumn{2}{|l|}{46.164} & 119 & & & & & \\
\hline \multicolumn{10}{|c|}{ a. Dependent Variable: Overall Performance } \\
\hline \multicolumn{10}{|c|}{ b. Predictors: (Constant), Business Integration, Innovation, Joint Venture, Strategic Alliance } \\
\hline \multicolumn{10}{|c|}{ Coefficients $^{\mathrm{a}}$} \\
\hline \multirow[t]{2}{*}{ Model } & & & \multirow{2}{*}{\multicolumn{4}{|c|}{$\begin{array}{lll}\text { Unstandardized Coefficients } & \begin{array}{l}\text { Standardized } \\
\text { Coefficients }\end{array} \\
\text { B } & \text { Std. Error } & \text { Beta }\end{array}$}} & \multirow{2}{*}{\multicolumn{2}{|c|}{$\mathrm{t}$}} & \multirow[t]{2}{*}{ Sig. } \\
\hline & & & & & & & & & \\
\hline \multirow{5}{*}{1} & (Constant) & & 1.169 & .049 & & & & 733 & .000 \\
\hline & Joint Venture & & .096 & .010 & .192 & & & & .000 \\
\hline & Innovation & & .322 & .014 & .433 & & & 384 & .000 \\
\hline & Strategic Alliance & & .272 & .018 & .544 & & & 342 & .000 \\
\hline & Business Integrat & ion & .030 & .017 & .060 & & & & .082 \\
\hline
\end{tabular}

a. Dependent Variable: Overall Performance

The results show a strong positive correlation between grand strategies and performance ( $\mathrm{r}=0.992)$ and statistically significant influence of the strategies on performance $\left(r^{2}=0.984 ; p<0.05\right)$. Joint venture, innovation and strategic alliance strategies have statistically significant independent influence $(\mathrm{p}<0.05)$ while business integration strategy has statistically not significant independent influence $(\mathrm{p}>0.05)$. Strategic alliance account for a higher unit change in performance $(\beta=0.544)$. This can be represented as:

$$
\mathrm{Y}=1.169+0.192 x_{1}+0.433 x_{2}+0.544 x_{3}+0.060 x_{4}+\varepsilon
$$

Where $\mathrm{Y}$ is the performance; $x_{1}$ is the joint venture, $x_{2}$ is the innovation, $x_{3}$ is the strategic alliance $x_{4}$ is the business integration and $\mathcal{E}$ is the precision error at $95 \%$ confidence level.

6.4 Competitive Strategies and Overall Performance

The combined influence of generic, growth, and grand strategies on performance was tested and the results are presented in Table 4. 
Table 3. Competitive strategies and performance

Model Summary
$\begin{aligned} & \text { Model } \\ & \text { R R Square }\end{aligned}$

a. Dependent Variable: Overall Performance

The results show a strong positive correlation between competitive strategies and performance $(r=0.988)$ and statistically significant influence of the strategies on performance $\left(r^{2}=0.976 ; p<0.05\right)$. All competitive strategies have statistically significant independent influence $(\mathrm{p}<0.05)$ with growth strategies reporting negative influence and grand strategies accounting for a higher unit change in performance $(\beta=0.718)$. This can be represented as:

$$
\mathrm{Y}=0.459+0.366 x_{1}-0.058 x_{2}+0.718 x_{3}+\varepsilon
$$

Where $\mathrm{Y}$ is the performance; $x_{1}$ is the generic strategies, $x_{2}$ is the growth strategies, $x_{3}$ is the grand strategies and $\varepsilon$ is the precision error term.

\section{Discussion of Findings}

The study sought to determine the influence of competitive strategies on performance of construction companies in Kisumu County. The study established that the construction companies adopted all the categories of competitive strategies used in the study. These are generic strategies (cost leadership, differentiation, and focus strategies); growth strategies (market penetration, market development, product development, and diversification) and grand strategies (joint venture, innovations, strategic alliance, and business integration).

The study findings indicate that generic competitive strategies if adopted alone will account for $88 \%$ variation in firm performance; growth strategies will account for $59.7 \%$ and grand strategies account for $98.4 \%$. These findings are similar to other previous study carried out by Kalia (2012) which established that the three broad competitive strategies (generic, growth and grand) had varying levels of influence on firm performance if adopted independently.

The findings of the research established that $97.6 \%$ of the change in performance of the construction companies is explained by the combined of the competitive strategies. Grand strategies had the greatest contribution to unit change in performance of the construction firms followed by generic strategies. Growth strategies report negative contribution to performance. Overall, competitive strategies reported statistically significant influence on the performance of the construction companies ( $\mathrm{p}<0.05$ ). The findings are consistent with the findings of Machuki (2011) that established that competitive strategies is a major factor that plays a vital part in deciding firm performance. 
This study established that cost leadership strategy has influence on performance of construction companies. The findings are consistent with other previous study done by Brooks (1993) that established that a cost leadership strategy is intended to create low-cost products as compared to the competitors by putting more emphasis on cost-effective output. The study concluded that the companies were consistent with low-cost strategy features, which includes: company pricing its products lower than its rivals; the company buying in bulk to reduce cost; the company is very strict on wastage of materials; the company outsourcing some functions which are not core to reduce costs; the company employing new technology to reduce costs; the company cutting costs on overheads such as human resource to reduce costs. These findings are in agreement with a previous study done by Brooks (1993) that found out that a company can establish a superior cost advantage over its enemies and gain large market share or earn higher profit margin.

The study also revealed that performance of construction firms is influenced by differentiation strategy. This concurs with a past research that found out that differentiation is a showcasing procedure utilized by a firm to build up solid character in a particular market; additionally referred to as segmentation strategy (David, 2000). This is principally through features such as the company is packaging same service or product in different ways to target different markets; the company is employing company branding to differentiate itself and products from other competitors; the company is laying emphasis on improving quality and producing high end products; the company is providing budget for research and development; the company has well trained staff and the company has ability to handle customer complaints adequately. This contention is in agreement with Porter (2008) who argued that differentiation is seen to include formation of unique products or services. The findings are in agreement with McCracken, (2002) verdict that the critical tactic in formulating a differentiation strategy is to figure out what makes an organization not the same as a competitor's. If this strategy is to be successful, then the unique features should provide the customer with superior values. The unrivaled product as seen by the customer leads to reduced price elasticity of demand as the customer tend to be more loyal to the brand, hence providing a considerable level of insulation from competition.

The study further established that focus strategy has influence on the performance of construction companies through aspects such as the company is laying emphasis on county government projects; the company focuses on roads projects; the company is targeting building projects; the company focuses on projects from private developers; and the company focuses on national government projects. The study findings are in agreement with previous studies that equally observed that successful focus strategy gives the seller a competitive edge over its rivals since most buyers view the products/services as superior and unique (Stone, 1995). The findings are in agreement with other findings that have argued that a firm can pick to concentrate on a specific product or service range, topographical zone or select client group. The focus strategy endeavors to take care of the requirements of a specific market segment, regardless of whether based on differentiation or low-cost.

The research also established that performance of construction firms in Kisumu County is influenced by growth strategies. This is highlighted by Porter (2008) who argues that companies grow new products focused on its current trade sections and by expanding rapidly into new ventures by growing modern products for modern markets. And is accomplished by the following features; the company is expanding and opening branches in other regions; the company is working to enhance its deals in the market; the company is working towards being a "Design Build" firm; the company is also supplying of construction materials; and the company is venturing in the real estate industry. The findings compliment a past report that contends that the process of a company enlarging or varying its range of products or field of operations is the most unsafe of the growth strategies as it needs both resource and trade improvement and might be one of the company's core abilities (Barney 2002).

The study further revealed that grand strategy has influence on performance of construction companies in Kisumu County. The research revealed that partnerships and alliances increased the synergies of the two organizations and if the arrangements are done carefully both organizations can benefit immensely. This is through aspects such as the company participates in joint venture bidding \& works; the company readily adopts new building technologies; the company works with other firms in strategic alliances; and the company embraces business integration with other firms.

The discoveries in this investigation additionally agreed with the earlier discoveries of Wambugu (2012) whose research found that non-financial performance was to a larger extent affected by the strategy adopted though this was in a non-competitive environment. On financial performance, findings from earlier studies by Adhiambo (2009) and Obiero (2008) were confirmed after the research found out that different competitive strategies determined the performance of firms. An earlier study by Eunice \& Kepha (2013) examined the influence of competitive strategies on the performance of Kijabe Mission hospital. Their findings established that cost leadership strategy, 
differentiation strategy, focus strategy and growth strategy have a significant effect on the performance of an organization and corroborates the findings of this study. A study by Kimani \& Douglas (2014) sought to find out the influence of competitive strategies on performance of farmers cooperatives in Butere Sub-County and established that cost leadership strategy had significant effect and was widely used, as well as focus strategy which also had a positive impact. They also observed that the farmers were not keen on differentiation strategy but noted it was a powerful tool that farmers could utilize to improve their performance, basically agreeing with the findings of this study.

\section{Conclusion}

From the study findings, a conclusion can be drawn along various dimensions. First, it can be concluded that construction companies in Kisumu County, Kenya adopt a mix of various competitive strategies that seek to enhance their performance. The strategies are broadly categorized as generic, growth, and grand competitive strategies as espoused by Porter (2008), Ansoff (1991) and Pearce and Robinson (1997).

Overall, all the categories of competitive strategies reported a strong positive correlation with performance. While all the categories of competitive strategies were found to have statistically significant influence on performance of construction companies in Kisumu County, the grand strategies accounted for a higher proportion of unit change in performance followed by generic strategies. The growth strategies had a negative contribution towards performance.

Independently, differentiation strategy accounted for a higher proportion of unit change in performance followed by market penetration strategy, strategic alliance and innovation in that order. This is in spite of the negative contribution by growth strategies' negative contribution to performance. This paves way for a conclusion that pursuing the competitive strategies simultaneously may have different implications on performance as compared with pursuing each competitive strategy independently. From the discussion of findings, it can be concluded that the results of this study have found support in both theory and extant empirical literature.

\section{Implications for Theory, Policy and Practice}

Both independent and combined influence of the studied competitive strategies reported statistically significant influence on performance. The research gives confirmation of the significant part that the management and competitive strategies of a company renders in deciding firm performance. It in this manner gives some credence to the game theory and strategic conflicts model whose real accentuation is on how ownership of key assets, plans, maneuvers and abilities empowers a company to pick up and maintain a competitive advantage.

On the policy front, the study implies that policy makers and the management of the construction companies in Kisumu County should adopt a mix of the competitive strategies since they have positive influence on performance of the companies. The management of construction companies should be ready to respond to the five elementary competitive forces that drive industry rivalry which incorporates risk of new participants; danger of substitute items; bargaining power of suppliers; bargaining power of buyers and rivalry among current competitors.

\section{Limitations and Suggestions for Further Research}

The study findings ought to be deciphered and comprehended inside the bounds of natural constraints. In the first place, this research did not accomplish $100 \%$ response rate. This is a result of high rate of non-response occasioned by hesitance of the respondents to return back the survey questions. Combined with constrained time and assets, endeavors of getting more reactions were incredibly impeded. In this manner, the accuracy of the outcomes could have been enhanced if more information were gotten for investigation. A similar study can be undertaken to target a response rate that is close to or $100 \%$.

Secondly, the research findings precision was also constrained to the degree to which the respondents were straightforward in responding to the questionnaires. Given the delicate nature of information gathered, there may have been probability of noting inquiries in certain way in order to abstain from giving away pivotal and private competitive trade innovations and secrets. This was despite assurance with the introduction letter that the study information would be used for academic purposes only and in a confidential manner. A study that's designed to obtain purely secondary objective data will definitely yield plausible results.

Thirdly, the research prevalently used regression in testing the influence of competitive strategies on performance. The decision was arrived at with presumption that the relation was direct or linear in nature. There is a probability that the connections between and among the variables is non-linear and along these lines testing their connections utilizing nonlinear regression models is probably going to result into distinctive outcomes. 
Lastly, the study was limited in scope since it covered Kisumu County resident construction companies, as such the recommendations of this study may only be applicable to a different industry or company at a minimal extent. The study was also limited to certain strategies whereas there are many more strategies which firms can adopt to remain competitive. A replicative study in other contexts is likely to yield results that can validate and/or invalidate the current study's findings.

\section{References}

Adhiambo, O. S. (2009). Competitive positioning and performance of commercial banks in Kenya. School of Business, University of Nairobi, Kenya.

Akan, J. J., Hofer, C. W., \& Boulton, W. R. (2006). Toward a system for classifying business strategies. Academy of Management Review.

Allen, R., Helms, M., Takada, M., \& White, C. (2006, January/February). Rewards and organizational performance in Japan and the United States: a comparison. Compensation \& Benefits Review, 7(14).

Ansoff, H. I. (1991). Critique of Mintzberg Henry. The Design School-Reconsidering the Basic Academy of Annual Best Meetings Proceedings.

Barney, J. B. (2002). Gaining and sustaining competitive advantage. Prentice Hall New Jersey.

Brooks, M. R. (1993). International competitiveness: assessing and exploring competitive advantage by ocean container carriers. Logistics and Transportation Review, 3(23), 275-293.

Camerer, C. (2003). Behavioral Game Theory. New Jersey: Princeton University Press.

Chan, R. Y., \& Wong, Y. H. (1999). Bank generic strategies: does Porter's theory apply in an international banking center. International Business Review, 8(5), 561-590. https://doi.org/10.1016/S0969-5931(99)00020-7

Cooper, D. R., \& Emory, W. (1985). Business Research Methods (3rd ed.). R.D Irwin.

David, F. R. (2000). Strategic Management: Concepts. Upper Saddle River, Prentice Hall Inc New Jersey.

Dess, G., \& Davis, P. (1984). Porter's (1980) generic strategies as determinants of strategic group membership and organizational performance. Academy of Management Journal, 27(3), 467-488.

Eunice, W., \& Kepha, O. (2013). Effects of Competitive Strategies on the Performance of Mission Hospitals in Kenya (A Case of Kijabe Mission Hospital). International Journal of Science and Research, 2(11), 3-20.

Hawes, J. M., \& Crittendon, W. F. (1984). A taxonomy of competitive retailing strategies. Strategic Management Journal, 5(2), 27-87. https://doi.org/10.1002/smj.4250050307

Hlavacka, S., Ljuba, B., Viera, R., \& Robert, W. (2001). Performance implications of Porter's generic strategies in Slovak hospitals. Journal of Management in Medicine, 15(1), 44-66. https://doi.org/10.1108/02689230110386489

Ingraham, R. (2005). Performance; promises to keep and miles to go. Journal of Management Studies, 65(4), 390-395.

Jassim, R. (2008). Competitive Advantage through the Employees. Research Paper, College of Technology, Jeddah.

Kalia, M. A. (2012). Competitive Strategies Adopted by Chinese Firms in the Building and Construction Industry in Kenya. Unpublished MBA project. School of Business, University of Nairobi, Kenya.

Kaplan, R. S., \& Norton, D. P. (2006, January-February). Using the Balanced Scorecard as a Strategic Management System. Harvard Business Review.

Kaplan, R. S., \& Norton, D. P. (1993, September-October). Putting the Balanced Scorecard to Work. Harvard Business Review, 5, 134-147.

Karanja, E. (2010). Competitive Strategies Adopted by Standard (K) Limited. Unpublished MBA project. School of Business, University of Nairobi, Kenya.

Kenya National Bureau of Statistics. (2015). Economic Survey, pp. 204-208

Kimani, C., \& Douglas, M. (2014). Effects of Competitive Strategies Adopted By Farmers' Cooperatives on Performance in Butere Sub-County, Kenya. International Journal of Business and Management Invention.

Lester, R. (2009). Made in America. MIT Commission on Industrial Productivity. Boston.

Lim, J. (1999). Fun, Games \& Economics: An appraisal of game theory in economics. Undergraduate Journal of 
Economics, 3, 2-22.

Machuki, V. N. (2011). External environment-strategy coalignment, firm- level institutions and performance of publicly quoted companies in Kenya. Unpublished Ph.D thesis. University of Nairobi, Nairobi.

Mugenda, M., \& Mugenda, G. (2003). Research Methods, quantitative and qualitative approaches. Nairobi, Acts Press.

Obiero, H. O. (2008). Competitive Strategies Applied by Cement Manufacturing Firms in Kenya. Unpublished MBA project, School of Business, University of Nairobi, Kenya.

Oluoch, J. K. (2016). Strategy Content, Quality Management Practices, Organizational Factors and Performance of ISO 9000 Certified Middle Level Colleges in Kenya. Unpublished Ph.D thesis. University of Nairobi, Nairobi.

Osborne, J., \& Rubinstein, A. (1994). A Course in Game Theory. London: Massachusetts Institute of Technology.

Oyeila, B. (2011). Completive Strategies and Performance of Commercial Banks in Kenya. Unpublished MBA project. School of Business, University of Nairobi, Kenya.

Pearce, J. A. II., Mittal A., \& Robinson, R, B. (2010). Strategic management; formulation, Implementation and Control (10th ed.), Special Indian Edition. New Delhi, India: Tata McGrow- Hill.

Porter M. E. (2000). Competitive Strategy: Techniques for Analyzing Industries and Competitors. Free Press, New York.

Porter, M. E. (2004). Competitive strategy: techniques for analyzing industries and competitors. The Free press.

Porter, M. E. (2005). Competitive Advantage strategies: Creating and Sustaining Superior Performance (with a New Introduction). Free Press, New York.

Porter, M. E. (2008). Competitive strategy: Techniques for analyzing industries and competitors.

Powers, T. L., \& Hahn, W. (2004). Critical competitive methods, generic strategies, and firm performance. The International Journal Bank Market, 22(1), 43-64. https://doi.org/10.1108/02652320410514924

Reynolds, R. L. (2005). Basic micro economics: An outline. Alternative Microeconomics Part II.

Shapiro, C. (1989). The theory of business strategy. RAND Journal of Economics, 20(1), 125-137. https://doi.org/10.2307/2555656

Stone, M. (1995). Strategic development related to Europeanization of UK logistics and distribution service suppliers. European Business Review, 95(5), 9-14. https://doi.org/10.1108/09555349510147444

Teece, D. J., Pisano, G., \& Shuen, A. (1997). Dynamic capabilities and strategic management. Strategic $\begin{array}{lll}\text { Management } & \text { Journal, } & \text { 18(7), }\end{array}$ https://doi.org/10.1002/(SICI)1097-0266(199708)18:7<509::AID-SMJ882>3.0.CO;2-Z

Thompson, A., \& Strickland, A. J. (2010). Strategic Management: Concepts and Cases. Irwin, New York.

Van Doreen, A. (2010). A multi-dimensional analysis of local economic development in Graff-Reinet, Eastern Cape. Journal for New Generation Science, 8(1), 11-28.

Wambugu, I. M. (2012). Competitive Strategies and Performance of International Non-Governmental Organizations in Nairobi. Unpublished MBA project. School of Business, University of Nairobi, Kenya.

Yamane, T. (1967). Statistics, an Introductory Analysis (2nd ed.). New York: Harper and Row. 